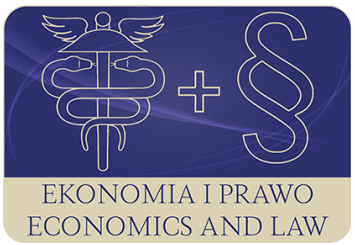

EKONOMIA I PRAWO. ECONOMICS AND LAW

Volume 15, Issue 4, December 2016

p-ISSN 1898-2255, e-ISSN 2392-1625

www.economicsandlaw.pl

ORIGINAL ARTICLE

received 24.11.2016; revised 25.01.2017; accepted 25.01.2017

Citation: Kilanowski, M. (2016). The questionable role of experts in global governance. Beyond David

Kennedy approach. Ekonomia i Prawo. Ecomomics and Law, 15(4): 481-491.

doi:10.12775/EiP.2016.032.

\title{
The questionable role of experts in global governance. Beyond David Kennedy approach
}

\author{
MARCIN KILANOWSKI \\ Nicolaus Copernicus University, Faculty of Law and Administration, Department of Law Theory \\ and State, ul. Władysława Bojarskiego 3, 87-100 Toruń, Poland \\ \markil@umk.pl
}

\section{Abstract}

Aim: This article focuses on the role of experts in creating regulations and policies on the global level.

Motivation: The question that should be answered is what role do experts actually play, what do they represent, how are they elected, and how accountable are they. The analysis

will start by presenting M. Foucault and D. Kennedy arguments regarding knowledge and the role of experts. It will be argued that experts not only represent 'knowledge' but also different intuitions and presumptions. They are subject to various institutional pressures, to interests combined with values and to the politics of daily life.

Results: We should be aware of that and to see that the dichotomy of knowledge and politics collapses, that there is no longer pure knowledge that is detached from politics.

Unfortunately we are not aware of that, especially when experts use the language that supports the outcome that is desired. In effect, they preserve the private law actors-public law actors dichotomy, because it serves, for example, the interests of multinational corporations, not to expend the scope of their responsibility. In the light of this we can say that changing our understanding of knowledge should also change our understanding of law as separate from politics, as mirroring a reality thanks to those that know best. With this mind, we can start to look for better ways of holding experts accountable for what they do and to try to ensure transparency in the process of creation of regulation and policy formation. 
Keywords: experts; power relations; dichotomies; corporate governance; global governance; transparency; accountability

JEL: Z13

\section{Introduction}

Global governance is 'a dynamic process in which legal, political and economical arrangements unleash interests, change the balance of force, and lead to further reinvention of the governance scheme itself' (Kennedy, 2008, p. 832). Among the many actors participating in the global governance processes and in shaping the international legal order, a particular role is assigned to experts. It is important to know what role experts play in the process of formation of international law and global governance. Recognition of the role experts play is underdeveloped nowadays. This is why we should make a further step to understand who plays a role in the developing of global governance regime. Experts are part of these processes - often without being aware of the different relations they are part of which determine outcomes of their work and of the ideological or doctrinal biases they are driven by (Benforado \& Hanson, 2012; Chen \& Hanson, 2004, pp. 1103-1253). Higher understanding will secure a higher level of transparency and legitimacy of within these process and will help to strengthen accountability among experts.

Before the shift toward more transparency, legitimacy, and accountability can take place the following must occur. First, we should understand the role that such legal actors as experts play and we must become aware that processes in which they are involved are part of the structures of power as knowledge is (Collins \& Evans, 2006, pp. 39-110). Second, we should understand how the language of law constrains us and, and open it for criticism. Finally, we have to allow people to participate in these processes. So far we have neither people participating in this processes nor appropriate legal institutions that would support such participation. For that to happen, we should be free, and not to be constraint by, the networks of power. More freedom will come with consciousness of the existing relations and biases, ideologies and doctrines that play a role in the formation of law and international institutions by experts. We need less imposed top-down fixed knowledge and regulations, and more bottom-up formation processes especially when we deal for example with transnational corporations.

Of course we should be aware that transparency and knowledge will be never fully achieved. We have to accept that conflict is part of democracy, that knowledge is fallible, and that the law has to change in order to face new challenges and react to changing needs of the people. History is not over in any sense: history of law, history of legal institutions, and history of governance. This notwithstanding, we should not stop pursuing knowledge if an international global

${ }^{1}$ On the issue of the possibility of transparency and legitimacy in international law please see: Koskenniemi (2006). 
governance regime is to be established in a form desired by those that care about democracy.

\section{Knowleadge is shaped by power relation - lesson of Foucault}

As D. Kennedy (2005a, pp. 5-6) says our world is an 'ongoing project of regulation and management'. To understand it, we have to present a 'compelling account of the actual global governance regime'. One can ask, however, if that is possible after Foucault - if any pure knowledge functioning of a global governance regime is possible? According to Foucault (1979, pp. 27-28), 'it is not the activity of the subject of knowledge that produces a corpus of knowledge, useful or resistant to power, but power-knowledge, the processes and struggles that traverse it and of which it is made up, that determines the forms and possible domains of knowledge'. Foucault's idea is that there is no way of looking for knowledge outside power structures, and power relations and vice versa. 'Power and knowledge directly imply one another (...) there is no power relation without the correlative constitution field of knowledge'.

Foucault's perspective might be useful for us to better understand any attempts to create a global governance regime that would result in more 'protection of private rights', 'promotion of democracy', 'responsibility', 'public good', and 'welfare'. Foucault's analysis seems to be more valuable now than ever before in a world in which we are trying to strengthen our understanding of humanitarianism, law of war, functioning of the state, transnational corporations, and of a 'common vocabulary'. We know already that what may at first look like a global effort to promote peace in the end becomes a set of institutional and bureaucratic practices that start to function through vocabulary that promotes war, 'fought and legitimated, rather then restrained' (Kennedy, 2005a, p. 10). We see that we can overlook the 'dark sides' of initiatives, which may have a humanitarian form but not a humanitarian effect (Kennedy, 2004, p. 112). We now understand that old notions like 'sovereignty' should be redefined. These days it is more obvious than ever that the various power relations that states are a part of determine their domestic interest rates or preferred tax policy. The same is true about functioning of corporations, which create consequences not only for their shareholders but for the larger public. In that way they become important actors of the public sphere however they are not held responsible for consequences they produce.

\section{Analyzing the role of experts}

We can of course say that 'in our world, power lies in the capillaries of social and economical life. Myriad networks of citizens, commercial interests, civil organizations and government officials are more significant than interstate di- 
plomacy' (Kennedy, 2005a, p. 3). But can we possess unconstrained knowledge about such processes?

A natural strategy these days is to turn to experts for the answer. However if we look in a critical way, we will see how these experts function in the background of the political and the public, what 'blunts the responsibility of the actors in the foreground, while affirming their centrality' (Kennedy, 2005a, p. 5 ). Such situation not only blunts the responsibility of political leaders, but also of experts functioning in the background. We see that these are the experts who often define for us what happens in the foreground - in the political sphere. They also interpret facts for politicians, legislators and judges. Through that they form the context, the background, and by that provide a framework for decisions. In that process very crucial is the language they use which also becomes part of legal language and legal norms they help to develop. So to a great extent it is no longer political leaders or even to some extend the judges who decide but the experts. Experts, however, often do not perceive themselves as the ones that do decide and they deny their responsibility (Kennedy, 2005a, p. 11).

As D. Kennedy points out, we are increasingly governed by various experts who make decisions regarding global challenges. And we see that their decisions are sometimes more important for dealing with global wealth and problems of poverty than those of politicians. Because of that we should be worried about the role experts play for two reasons. First, it may lead to the blunting of the responsibility of those in the foreground - namely, political leaders. Second, it may blunt our ability to recognize the possible irresponsibility on their side. They are also not free from the power play. And they can be more dedicated to defend their position than care about the outcomes of their decisions (Robbins, 1993). Their position of power in power structures may play a more important role than the goals that were set up with support of the language that was once shaped to defend those goals. Their position and language can be - as happened with the humanitarian vocabulary during the time of the war in Iraq - used to asses, measure, and judge the necessity of self-defense and to legitimate war. As a consequence, 'humanitarian expertise gave progressives an easy - and irresponsible way out' from dealing with the problem, and became a perfect example of Foucault's knowledge-power entanglement (Kennedy, 2005a, p. 21-20)

By analyzing the particular work of 'experts', and facing crisis after crisis that resulted from the work of some of these experts, we become more skeptical about gaining unconstrained knowledge about the global problems we face, and about holding involved actors accountable. Is there another way to gain such knowledge and establish 'the experience of responsible human freedom among the experts who govern the world' (Kennedy, 2005a, p. 1) and also among other actors? It looks that if one wants to overcome some part of the problem Foucault has described one has to understand possible power relations that are not visible to us at the moment. That can happen if we will start to understand the processes that governs the election of experts, if it is democratic, how that happens that a person becomes a representative of a country in the framework 
of international organizations or particular international conferences. One can also hope that this will be possible if we tide the election of experts with nationally based democratic processes. Of course national democratic processes are also part of the power game and are part of a complex structure of power relations that shape everything ${ }^{2}$. But at least there is a possibility of working toward transparency in these processes. In these processes not only political leaders should play a role, but also experts clearly expressing their political and ethical position, the choice of legal doctrine, as well the people should play a role ${ }^{3}$. Shortly speaking we should start to understand in a more comprehensive way the various power relations that are involved in the process, what can lead to creation of a system of expert accountability.

There are legal possibilities of establishing the above-mentioned conditions if the process of formation will be open enough to allow for critical assessment of the situation (Mansbridge, 2008, pp. 251-271). This assessment can be presented from many angles, but it is crucial to begin with an approach that shows the role experts play because such an approach will cut into the heart of the problem - of knowledge not being independent from politics. It is especially visible when we see that that yesterday's experts become today's politicians and vice versa. In such a state, it is difficult to determine where being an expert starts and where it ends. Where is knowledge and where is politics? Politics shifts into 'knowledge' and 'knowledge' into politics. With different times come different roles. It becomes clear that the dichotomy of politics-knowledge (and more narrowly: legal expertise) is too simplistic, too broad, to describe the complexity of the situation.

\section{Experts and the language of dichotomies}

Unfortunately experts use the language based on dichotomies. However, in light of the above, one can say the picture is complex and dichotomies can not grasp it. Unfortunately, we do not perceive that way, that the language based on dichotomies like knowledge-politics, politics-law is detaching us from reality, that it constrains us from coming up with other valuable solutions to current problems. That is also the case with the way we use - following the language based on 'knowledge' provided by many experts - the dichotomy private law actors-public law actors. In reality the distinction is not that sharp, but it is still used by experts and it is preserved by the legal language and forms the basis for different policies (Bourdieu, 1991, pp. 655-669). Such language is for example the basis for the formation of regulations of transnational companies by inter-

${ }^{2}$ More on the issue see: Michelman (1998, pp. 1717-1734) or Parker (1994).

3 About the role that unexpressed different legal doctrines play in decisions of arbitrators and judges. Please see: Gaillard (2010, pp. 1-11). 
national law ${ }^{4}$ and during litigation ${ }^{5}$. It is also used by corporations and their experts during the formation of law. In reality corporations as legal entities not only behave as private entities but are also involved in regulation of not only what is private but also of what is public, even though they continue to repeat that they are only private law actors (Danielsen, 2006, pp. 85-99; Ruggie, 2004, pp.10-15).

Corporations create such regulations in many ways. They are involved in shaping rules through lobbying and interpreting rules that they later apply at their discretion. Moreover, they create their own rules by certain business practices or private dispute resolution mechanisms. These rules can be used when local legal regulations do not exist or are not developed. All of these and much more form what is called corporate governance. It has an impact on national and global governance effects (Danielsen, 2005, pp. 411-425; Roe, 2003, pp. 21-28). In the light of this we can say that through experts, corporations are national or transnational 'public' regulators - they regulate, but with different goals - for example, to strengthen their international market position vis-a-vis regulations of competition established by the states, or vis-a-vis international labor or environmental standards. Such strategy is unfortunately short-sided. There is a pressing need for corporate governance rules to reach beyond the dichotomy of private law actor-public law actor because of the corporate regulatory power and its impact (Danielsen, 2010, pp. 49-68; Braithwaite \& Drahos, 2008).

There are some projects nowadays that deal with reshaping the position corporations play on a global stage and in international law, from regulatory projects to administrative ones ${ }^{6}$. There are also ones that point to the responsibility of corporations and the need for their participation as actors of not only private international law but also public international law (Ruggie, 2010, 2008). They are however limited in their approach as long as there are not presenting the role experts play in preserving the dichotomy mentioned above and the need of overcoming a sharp use of that dichotomy.

Of course according to the scholarship it may look as if we are moving in international law toward acceptance that corporations as private law actors have an impact on the public sphere. We often talk nowadays about social responsibility of corporations. The idea of social responsibility of corporations is today a conventional wisdom. However, we are still entrenched in the old way of thinking and the legal language still mirrors the old divisions of responsibility for the public sphere between state and corporations and in fact leads to lack of responsibility of both.

${ }^{4}$ For example during the process of shaping the 'Norms on the responsibilities of transnational corporations and other business enterprises with regard to human rights'.

5 As for example in the ATS Kiobel Case.

${ }^{6}$ Please see Danielsen (2005, 2006, 2010) works on corporations as an example of regulatory approach (mentioned above) and the work of Kingsbury et al. (2005) as example of administrative approach (mentioned further on). 
What can we do in such a situation? So far, the bright lines between what is the role of private actors and what is the role of states seems to be preserved by regulators and "experts' will reach beyond the private actors-public actors sharp dichotomy and consequences it produces. It can be said that we should see 'the decentralized and non-harmonized complexity of the global governance regime as a terrain filled not only with obstacles and pitfalls, but also with benefits and opportunities for the pursuit of social welfare purposes'. Thanks to that we could strengthen 'our creativity and effectiveness in shaping global power for the public good' (Danielsen, 2006, p. 99).

\section{Toward more accountability and the democratic processes}

To change the above we should strengthen our consciousness about the process and also establish more experts accountability and transparency of the processes they are involved in. By that we will strengthen the role of the people. The people are the ones that pay taxes, that send their sons and daughters to serve in UN peacekeeping operations, that care about ILO standards in the work place, and live by human right standards in their daily lives. If we really want more protection of rights, promotion of democracy, and responsible use of freedom, then these should be achieved not only by institutional redesign involving experts at the top-down level (unclear to the wider public), but also through bottom-up processes, through public engagement of the people ${ }^{8}$. Such public participation and oversight of the work of experts will not only inform the people about the projects and strategies under construction or the ones that are in use. That will also constrain those involved in the process of shaping and redesigning institutions or taking political or legal decisions so that their knowledge will not be totally overtaken by the power of their authority, ideological and doctrinal biases, by those who finance it, or political pressure imposed on them.

That will definitely lead to disaggregation of the system we know. Disaggregation and decentralization of the old systems should empower people to engage in shaping of a 'common vocabulary' of international law and law in general on different basis than sharp dichotomies existing in the vocabulary, which for now is shaped without transparency among experts ${ }^{9}$. This is why the international law-making processes is still, to a wide extend, a play of different level

7 Future of Aliens Tort Statue Litigation is no longer clear right now as well as holding corporations accountable for their human rights violations beig part of their usual bussines activities on the global stage after the ruling in the ATS Kiobel Case. On ATS see: Hufbauer \& Mitrokostas (2004, pp. 245-262).

8 Such aproach would mirror to a certain extend the bottom-up approach presented as a solution to the problems of creation of global administratove law, which main problme is lack of transparency, accountability and democratic review (Kingsbury et al., 2005, p. 55).

9 On common vocabulary see: Kennedy (2005b, p. 26, p. 42) or Michelman (1989, pp. 256-269). 
of specialists/experts. Contrary to that we should establish more than just networks of experts and include also people in the deccision process, even if they role would only be to listen. Such 'participation' of the people - of a country, region, of the world - in international law formation exist only in a limited way today, such participation is difficult and exceptional ${ }^{10}$. And that should not be the case.

Of course one could raise the objection that empowering the people in the above scenario will lead to 'diffusion of decision making in a multi-level system' and that powerful states or corporations can still have a greater influence on the process. However, it would not be right to say that such a model would not be applicable for understanding and solving global problems because nowadays there is a lack of central law-making authority or 'delegation of powers from... national democratic organs'. It is inappropriate to think that we can 'ensure accountability to the emerging international community as such' by 'different institutional mechanisms - mechanisms that are in some cases perhaps entirely detached from democratic foundations, and are more pragmatic means of checking the power (...) of the actors' (Kingsbury et al., 2005, pp. 56-57). First of all the context for global governance has changed and one can hardly imagine that there is a unified 'international community' speaking in one unified moral voice (Kennedy, 2006, p. 177) ${ }^{11}$. Second, it is also hard to imagine that there are more pragmatic means than the evaluation of certain strategies in a real-life setting - among those that should be primarily involved - the people. Such evaluation can secure us from the danger that the "myth of professional progress hinders the pragmatic assessment of specific initiatives' (Kennedy, 2005a, p. 22). There is a danger in thinking that the natural and necessary way of evolution is from democracy toward expert rule and the set up of institutional and legal mechanisms that will "stop the conversation"12. If one wants to evaluate how the world is governed, then it must be done through the use of democratic foundations. This process must be tied to the people, to culture, to the politics of the place and communities, and to the people's knowledge about them ${ }^{13}$. We should not forget that 'policy pragmatism can be thrown off by the blind spots and biases in the professional vocabularies' (Kennedy, 2004, p. 112).

${ }^{10}$ There are many initiatives leading to democratization of the production of the law in a local level. As far as international law is concerned the situation changes and the participation of the 'people' is still more difficult and exceptional.

${ }^{11}$ Kennedy (2006, p. 178) says futher that there is no unified international community of the same moral and unified commitments - 'such a community does not exist (...) the context for global governance has changed, reducing the space — and plausibility — for an 'international community' to speak with a single ethical voice'.

12 Such a future is envisaged in: Hansmann \& Kraakman (2004, pp. 33-68)

${ }^{13}$ For importance of culture and the politics of the place see: Kennedy (2008, p. 835). 


\section{Conclusion}

Opening the process of creation of regulations and policies for analysis and discussion can protect us from being blind to such biases and power play and react appropriately when they start to shape. It is important to note that we still lack a decentralized view of the world in which we live that will allow people to be more involved and question the status quo. For that to happen first we should gain a broader understanding of our present world by understanding the role that experts play in the networks of power-knowledge, through which they shape legal and political regimes and going beyond the language they use based on the notion of knowledge separated from politics and based on the dichotomy private law actors-public law actors. Secondly we should look for alternative legal and political accountability mechanisms to allow for coverage of a higher number of actors - including experts. It is of course necessary to "expand our ability to act through the capillaries of private quality standards or investments guidelines, ... property regulations and all the other norms and institutions which affects the use of force'(Kennedy, 2005a, p. 10), but that also means understanding the role experts play in this process of formation of regulation and policies which sometime may at best look like window dressing and at worst as manipulation in the name of powerful interests (e.g., governments, political parties, or corporations) - and to hold them more accountable. Thirdly, we need legal and institutional arrangements based on the language that goes beyond the private law actors-public law actors dichotomy that will shape disaggregated forms of governance, which we have today, into forms that will allow people to participate fully in the processes of formation, creation, and control. Of course, we need participation of the people itself. In other words, we need institutional redesign and public engagement. We need to establish relations between institutions and the people that will be serving the goals that we want to reach: promotion of democracy, creation of public good, and responsible use of freedom.

\section{References}

Benforado, A., \& Hanson, J. (2012). Atrubitions and ideologies: two divergent visions of human behavior behind our laws, policies and theories. In: J. Hanson (Ed.), Ideology, psychology and law. New York: Oxford University Press. doi:10.1093/acprof:0so/9780199737512.001.0001.

Bourdieu, P. (1991). Universal Corporatism: The Role of Intellectuals in the Modern World. Poetics Today, 12(4).

Braithwaite, J., \& Drahos, P. (2008). Regulatory Capitalism: How it Works, Ideas for Making it Work Better. Cheltenham: Edward Elgar Publishing Limited.

Chen, R., \& Hanson, J. (2004). Categorically Biased: The Influence of Knowledge Structures on Law and Legal Theory. Southern California Law Review, 77. 
Collins, H.M., \& Evans, R. (2006). The Third Wave of Science Studies: Studies of Expertise and Experience. In E. Selinger, \& R.P. Crease (Eds.), The Philosophy of Expertise. New York: Columbia University Press.

Danielsen, D. (2005). How Corporations Govern: Taking Corporate Power Seriously in Transnational Regulation and Governance. Harvard International Law Journal, 46(2).

Danielsen, D. (2006). Corporate Power and Global Order. In A. Orford (Ed.), International Law and its Others. Cambridge: Cambridge University Press.

Danielsen, D. (2010). Local Rules and a Global Economy: An Economic Policy Perspective. Transnational Legal Theory, 1(1). doi:10.1080/20414005.2010.1 1424501.

Foucault, M. (1979). Discipline and Punish. The Birth of the Prison. New York: Vintage Books.

Gaillard, E. (2010). The Representations of International Arbitration. Journal of International Dispute Settlement, 1(2). doi:10.1093/jnlids/idq012.

Hansmann, H., \& Kraakman, R. (2004). The End of History For Corporate Law. In J.N. Gordon, \& M.J. Roe (Eds.), Convergence and Persistence in Corporate Governance. Cambridge: Cambridge University Press.

Hufbauer, G.C., \& Mitrokostas N.K. (2004). International Implications of the Alien Tort Statute. Journal of International Economic Law, 7(2). doi:10.1093/jiel/7.2.245.

Kennedy, D. (2004). The Dark Sides of Virtue. Princeton: Princeton University Press.

Kennedy, D. (2005a). Challenging Expert Rule: The Politics of Global Governance. Sydney Journal of International Law, 27(1).

Kennedy, D. (2005b). Of War and Law. Princeton: Princeton University Press.

Kennedy, D. (2006). Leader, Clerk or Policy Entrepreneur? The Secretary General in a Complex World. In S. Chesterman (Ed.), Secretary or General? The UN Secretary-General in World Politics. Cambridge: Cambridge University Press.

Kennedy, D. (2008). The Mystery of Global Governance. Ohio Northern University Law Review, 34(3).

Kingsbury, B., Krisch N., \& Stewart R. (2005). The emergence of Global Administrative Law. Law and Contemporary Problems, 68(3).

Koskenniemi, M. (2006). Fragmentation of International Law: Difficulties Arising from the Diversification and Expansion of International Law. Report of the Study Group of the International Law Commission. Retrieved 13.11.2016 from http:// legal.un.org.

Mansbridge, J. (2008). Deliberative Democracy or Democratic Deliberation? In S.W. Rosenberg (Ed.), Deliberation, Participation, and Democracy: Can the People Govern? New York: Palgrave Macmillan.

Michelman, F. (1989). Bringing the Law to Life: A Plea for Disenchantment. Cornell Law Review, 74(2). 
Michelman, F. (1998). Protecting the People From Themselves, or How Direct Can Democracy Be? UCLA Law Review, 45(6).

Parker, R. (1994). Here, the People Rule, A Constitutional Populist Manifesto. Cambridge-London: Harvard University Press.

Robbins, B. (1993). Secular Vocations: Intellectuals, Professionalism, Culture. New York: Verso.

Roe, M. (2003). Political Determinants of Corporate Governance: Political Context, Corporate Impact. Oxford: Oxford University Press. doi:10.1093/acprof: oso/9780199205301.001.0001.

Ruggie, J. (2004). How to Marry Civic Politics and Private Governance. In A. Kuper (Ed.), The Impact of Corporations on Global Governance: A Report of the Empire and Democracy Project. Retrieved 13.11.2016 from http://www. carnegiecouncil.org.

Ruggie, J. (2008). Clarifying the Concepts of 'Corporate Sphere of Influence' and 'Complicity'. Retrieved 13.11.2016 from http://www.ohchr.org.

Ruggie, J. (2010). Protect, Respect and Remedy: The United Nations Framework for Business and Human Rights. In M. Baderin, \& M. Ssenyonjo (Eds.), International Human Rights Law: Six Decades after the UDHR and Beyond. Farnham: Ashgate Publishing.

\section{Acknowledgements}

Author contributions: author have given approval to the final version of the article. 
